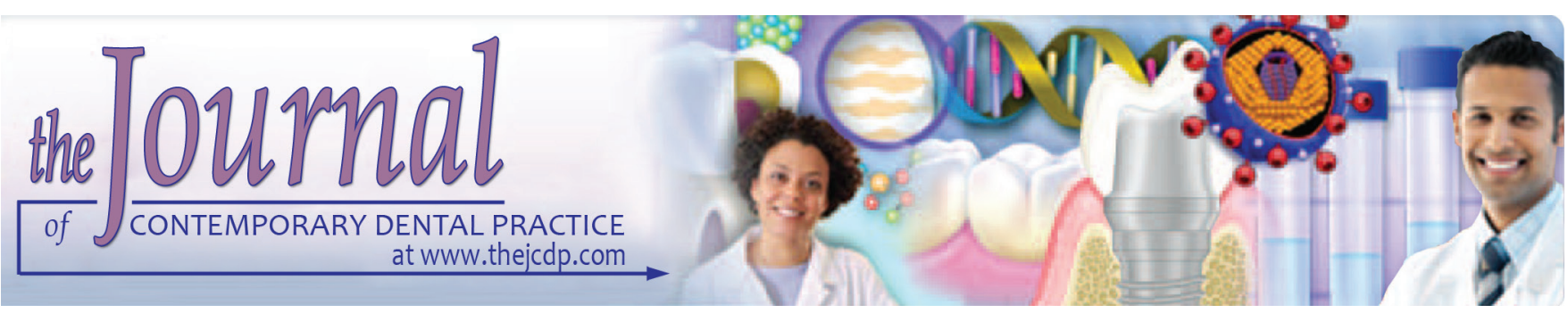

\title{
Antimicrobial Potential of Plant Extracts and Chemical Fractions of Sideroxylon obtusifolium (Roem. \& Schult.) T.D. Penn on Oral Microorganisms
}

\footnotetext{
${ }^{1}$ Thaíse PD Sampaio, ${ }^{2}$ Nathália AO Cartaxo-Furtado, ${ }^{3}$ Ana CD de Medeiros, ${ }^{4}$ Harley S Alves

${ }^{5}$ Pedro L Rosalen, ${ }^{6}$ Jozinete V Pereira
}

\begin{abstract}
Aim: The aim of this study is to evaluate the in vitro antimicrobial activity of plant extracts and chemical fractions of Sideroxylon obtusifolium T.D. Penn on Streptococcus mutans, Streptococcus oralis, Streptococcus salivarius, Streptococcus parasanguinis, and Candida albicans as well as to identify the chemical classes found in the bioactive extracts possessing better activity.
\end{abstract}

Materials and methods: Freeze-dried hydroalcoholic extracts of the bark and leaves (LC and LF respectively) and ethanol extracts of bark and leaves (EC and EF respectively) of S. obtusifolium were assessed for antimicrobial potential by determining the minimum inhibitory concentration (MIC), minimum bactericidal concentration, and minimum fungicidal concentration (MFC). The tests were performed by microdilution method (in triplicate) in three independent experiments. Phytochemical characterization was performed by quantification of total polyphenols, total flavonoids, and condensed tannins.

Results: The EC extract presented weak antimicrobial potential on the growth of $S$. mutans (MIC $=1000 \mu \mathrm{g} / \mathrm{mL}$ ); all extracts showed moderate inhibitory activity on the growth of $C$. albicans $(\mathrm{MIC}=500 \mu \mathrm{g} / \mathrm{mL})$. The dichloromethane and n-butanol fractions of LF extracts showed moderate growth inhibitory activity (MIC $=250 \mu \mathrm{g} / \mathrm{mL}$ ) on $C$. albicans and fungicide potential (MFC/MIC = 2). The phytochemical characterization revealed a

\footnotetext{
${ }^{1,6}$ Department of Dentistry, State University of Paraíba, Campina Grande, Paraíba, Brazil

${ }^{2}$ Department of Pharmaceutical Sciences, Federal University of Pernambuco, Recife, Pernambuco, Brazil

${ }^{3,4}$ Department of Pharmaceutical Sciences, State University of Paraíba, Campina Grande, Paraíba, Brazil

${ }^{5}$ Department of Pharmacology, Anesthesiology and Therapeutics School of Dentistry of Piracicaba, University of Campinas Piracicaba, São Paulo, Brazil

Corresponding Author: Thaíse PD Sampaio, Department of Dentistry, State University of Paraíba, Campina Grande, Paraíba Brazil, e-mail: thaiseuepb@gmail.com
}

predominance of total polyphenols $(E C=29.23 \%$; $L C=25.98 \%$ ) and condensed tannins ( $L C=38.84 \%$; LF $=17.78 \%)$.

Conclusion: The dichloromethane and n-butanol fractions of S. obtusifolium LF extract showed antifungal activity against C. albicans, with the potential for bioprospection of phytocompounds for the treatment of periodontal fungal diseases caused by this microorganism. The effect may be related to phytochemical compounds from the polyphenol and condensed tannin classes.

Clinical significance: Research for new oral microbial disease treatment alternatives in bioactive compounds from medicinal plants is of clinical relevance and scientific interest since many therapeutic antifungal agents do not obtain the effectiveness expected due to microbial resistance, or to adverse effects on human tissues.

Keywords: Candida albicans, Flavonoids, Laboratory research, Medicinal plants, Polyphenols, Sapotaceae, Streptococcus, Tannins.

How to cite this article: Sampaio TPD, Cartaxo-Furtado NAO, de Medeiros ACD, Alves HS, Rosalen PL, Pereira JV. Antimicrobial Potential of Plant Extracts and Chemical Fractions of Sideroxylon obtusifolium (Roem. \& Schult.) T.D. Penn on Oral Microorganisms. J Contemp Dent Pract 2017;18(5):392-398.

Source of support: Nil

Conflict of interest: None

\section{INTRODUCTION}

Biofilms are composed of small colonies of bacterial origin, nonrandomly organized in a matrix composed of water, extracellular polysaccharides, proteins, salts, and cells. It is known that there are specific intrabacterial associations in dental biofilm, which represent the main etiologic agents of several periodontal diseases, ${ }^{1-3}$ with Streptococcus mutans and Streptococcus sobrinus being the principal species associated with dental caries. ${ }^{3}$ 
Candida albicans are yeast often found in dental biofilms, increasing the production of exopolysaccharides and consequent accumulation of microbial mass, ${ }^{4}$ in addition to being responsible for oral candidiasis, the most common fungal infection in humans. ${ }^{5}$

The success of antimicrobial therapy requires the apparently contradictory roles of maintaining biofilms at levels consistent with the oral health, but without disrupting the beneficial properties of the resident microbiota. A major challenge for the future will be the development of products with satisfactory clinical efficacy, which preserves the benefits of the oral microbiota. ${ }^{6}$

In view of the resistance of microorganisms to antimicrobial substances known, experiments with medicinal plants in search of new bioactive compounds present themselves as a promising alternative. ${ }^{7,8}$ In addition, in vitro studies have demonstrated satisfactory antimicrobial activity from plant extracts. ${ }^{9}$

Sideroxylon obtusifolium (Roem. \& Schult.) T.D. Penn, Sapotaceae, is known as "quixaba" or "rompe-gibão." It extends from the semiarid northeast to the southeastern region of Brazil ${ }^{10-12}$ and is a native species from the "Caatinga" biome. ${ }^{13}$ The bark of the plant has been used by the population for traumas, pain in general, duodenal ulcer, gastritis, nausea, chronic inflammation, genital lesion, inflammation in the ovaries, kidney problems, heart problems, and diabetes. ${ }^{14}$ Infusions of the leaves are used as anti-inflammatories; however, information about the constituents of $S$. obtusifolium remains scarce. ${ }^{15}$

In Northeastern Brazil, because of its medicinal properties, S. obtusifolium is a popular plant species. Still, many plants frequently used by local populations have not been studied, and their active principles not identified to validate them as medicines nor to economically explore. ${ }^{16}$

In this perspective, the aim of this study was to evaluate the in vitro antimicrobial activity of extracts and chemical fractions of S. obtusifolium on S. mutans, Streptococcus oralis, Streptococcus salivarius, Streptococcus parasanguinis, and C. albicans, as well as identify the classes of chemicals in the bioactive extracts with the best activity.

\section{MATERIALS AND METHODS}

\section{Collection and Identification of Plant Material}

The bark and leaves of S. obtusifolium T.D. Penn were collected in the month of February 2013 in the semiarid region of Paraíba State, Sítio Capim Grande, rural area of the municipality of Campina Grande ( $7^{\circ} 22^{\prime} 25^{\prime \prime}$ S), Meso region of the Borborema, Paraíba State, Northeast Brazil. According to the current legislation (Provisional Measure No. 2.186/2001), which regulates the collection, access, and transportation/shipping of genetic heritage components, and access to associated traditional knowledge, we performed bark and leaf plant collections so as not to cause death or injury to the vegetal species. The S. obtusifolium T.D. Penn examples were deposited in the collection of the Manuel Arruda Câmara (School) Herbarium of the Paraíba State University - UEPB, identified with Voucher number: 583.

\section{Preparation of Plant Extracts}

The bark and leaves were cleaned and subjected to drying in an oven for air circulation (FANEM - Model 330/5) at $40^{\circ} \mathrm{C}$ until final weight stabilization, and subsequently crushed in a knife mill (SOLAB - Model SL 30) with a 10-mesh diameter. The yields of bark and leaves were 41.56 and $48.76 \%$ respectively, from their initial weight.

Hydroalcoholic extracts were produced at $70 \%$ and ethanol extracts at $96 \%$ of the S. obtusifolium bark and leaves, in the proportion of $200 \mathrm{gm}$ dried and ground plant to $1 \mathrm{~L}$ of solvent, by maceration method. The extracts were subjected to evaporation under reduced pressure in a rotary vaporizer at $40^{\circ} \mathrm{C}$ and $70 \mathrm{rpm}$. After this step, the hydroalcoholic extracts were dried at room temperature between $-20^{\circ} \mathrm{C}$ and $-40^{\circ} \mathrm{C}$. The following obtained extracts were tested as antimicrobials: Freezedried hydroalcoholic extracts of leaf and bark (LF and LC) and ethanol extracts of the leaf and bark (EF and EC). The extracts were packed in glass containers, protected from light and stored under refrigeration.

\section{Microorganisms and Susceptibility Testing}

We used strains of the American Type Culture Collection from the Fundação Oswaldo Cruz: S. mutans $(27,175)$, S. parasanguinis (903), S. salivarius (7073), S. oralis $(10,557)$, and C. albicans $(10,231)$. The preparation of the inoculum and susceptibility tests for determination of minimum inhibitory concentration (MIC) was performed according to the recommendations of protocol M7-A6 for bacteria ${ }^{17}$ and M27-A3 for yeast. ${ }^{18}$ For the reactivation of the microorganisms, preparation of the inoculum and the testing of antimicrobial activity we used brain heart infusion (BHI) broth culture - HIMEDIA ${ }^{\circledR}$ and BHI agar - media HIMEDIA $^{\circledR}$, plus $5 \%$ mutton blood lysate for bacteria, and sabouraud dextrose broth - HIMEDIA ${ }^{\circledR}$ and sabouraud dextrose agar - HIMEDIA ${ }^{\circledR}$ culture media for the yeast.

The freeze-dried hydroalcoholic and ethanol extracts were dissolved in ethanol at $40 \%$ yielding test extracts at the concentration of $4000 \mu \mathrm{g} / \mathrm{mL}$. The tests were performed according to broth microdilution method, in 96-well microplates. We deposited $100 \mu \mathrm{L}$ of the culture medium in all wells, and then added $100 \mu \mathrm{L}$ of the extract to be tested; the contents of the wells were homogenized and successive dilutions were performed. We added $100 \mu \mathrm{L}$ of the microorganism inoculum to be evaluated. 
For each concentration of the tested extract, we performed procedures in triplicate in three independent experiments. The concentrations of the extracts in the wells ranged from 1,000 to $15,625 \mu \mathrm{g} / \mathrm{mL}$. Control of the culture medium and control of growth of the microorganisms were realized with positive controls using chlorhexidine $0.12 \%$ for bacteria, and nystatin 100,000 IU/mL for yeast, and solvent control. The plates were incubated for 24 hours at $37^{\circ} \mathrm{C}$ in a microaerophilous environment for bacteria, and for 48 hours at $37^{\circ} \mathrm{C}$ for the yeast. After the incubation period was added $20 \mu \mathrm{L}$ of aqueous resazurin solution (Sigma-Aldrich ${ }^{\circledR}$ ) at $0.01 \%$ for visual reading of antimicrobial activity. ${ }^{19-21}$ The MIC was defined as the lowest concentration of antimicrobial agent, which prevented the visible growth of the microorganism in sensitivity tests, ${ }^{17}$ verified through change of the medium color.

For determinations of minimum bactericidal concentration $(\mathrm{MBC})$ and minimum fungicidal concentration (MFC), a portion of the well corresponding to MIC and previous wells was shown in agar BHI plus sheep blood (5\%) for bacteria, and agar sabouraud dextrose for yeast.

The MBC/MFC corresponded to the lowest concentration of the extract that prevented visible microbial growth in a solid culture medium. ${ }^{7}$

All procedures for the characterization of antimicrobial potential were performed in triplicate and in three independent experiments.

\section{Chemical Characterization}

The extracts with better antimicrobial activity were quantified for their contents of total polyphenols, total flavonoids, and condensed tannins.
For determination of total polyphenols, we used the Chandra and De Mejia Gonzalez method ${ }^{22}$; for determination of the total flavonoids content, we followed Meda et al method; ${ }^{23}$ the content of condensed tannins was quantified using the Makkar and Becker method. ${ }^{24}$ All analyses were performed in triplicate.

The freeze-dried hydroalcoholic extracts with better activity were fractionated using organic solvents in increasing order of polarity: Hexane, dichloromethane, ethyl acetate, and n-butanol. The final portion corresponded to the aqueous phase. Each extract fraction was evaporated under reduced pressure in a rotary evaporator at $40^{\circ} \mathrm{C}$, with a speed of $70 \mathrm{rpm}$, and then stored under refrigeration. All fractions were subjected to tests characterizing antimicrobial potential.

\section{RESULTS}

Table 1 presents the antimicrobial testing results (MIC, MBC, and MFC) of the S. obtusifolium hydroalcoholic freeze-dried and ethanol extracts.

Table 2 presents the phytochemical quantification of the freeze-dried S. obtusifolium hydroalcoholic and ethanol extracts for total polyphenols, total flavonoids, and condensed tannins.

Table 3 presents the antimicrobial potential of chemical fractions of the lyophilized hydroalcoholic extracts of S. obtusifolium bark and leaves against C. albicans.

\section{DISCUSSION}

Sideroxylon obtusifolium is a popular plant species in Northeastern Brazil because of its medicinal properties.

Table 1: Antimicrobial potential of chemical fractions of the lyophilized hydroalcoholic and ethanol extracts of bark and leaves of $S$. obtusifolium

\begin{tabular}{|c|c|c|c|c|c|c|c|c|c|c|}
\hline \multirow[b]{3}{*}{ Extracts } & \multicolumn{10}{|c|}{ Antimicrobial potential $\mu \mathrm{g} / \mathrm{mL}$} \\
\hline & \multicolumn{2}{|c|}{ S. mutans } & \multicolumn{2}{|c|}{ S. oralis } & \multicolumn{2}{|c|}{ S. parasanguinis } & \multicolumn{2}{|c|}{ S. salivarius } & \multicolumn{2}{|c|}{ C. albicans } \\
\hline & MIC & $M B C$ & $M I C$ & $M B C$ & $M I C$ & $M B C$ & $M I C$ & $M B C$ & MIC & MFC \\
\hline LF & $>1,000$ & * & $>1,000$ & * & $>1,000$ & * & $>1,000$ & * & 500 & $>1,000$ \\
\hline LC & $>1,000$ & * & $>1,000$ & * & $>1,000$ & * & $>1,000$ & * & 500 & $>1,000$ \\
\hline EF & $>1,000$ & * & $>1,000$ & * & $>1,000$ & * & $>1,000$ & * & 500 & $>1,000$ \\
\hline EC & 1,000 & 1,000 & $>1,000$ & * & $>1,000$ & * & $>1,000$ & * & 500 & $>1,000$ \\
\hline
\end{tabular}

${ }^{*}$ Testing was not performed due to lack of activity in the MIC test

Table 2: Quantification of total polyphenols, total flavonoids, and condensed tannins of the hydroalcoholic freeze-dried and ethanolic bark and leaf extracts of $S$. obtusifolium

\begin{tabular}{|c|c|c|c|c|c|c|}
\hline \multirow[b]{2}{*}{ Extracts } & \multicolumn{2}{|c|}{ Total polyphenols } & \multicolumn{2}{|c|}{ Total flavonoids } & \multicolumn{2}{|c|}{ Condensed tannins } \\
\hline & $\mathrm{mg} / \mathrm{gm}$ & $\%$ & $\mathrm{mg} / \mathrm{gm}$ & $\%$ & $\mathrm{mg} / \mathrm{gm}$ & $\%$ \\
\hline LF & $223.77 \pm 37.52$ & $22.37 \pm 3.75$ & $17.03 \pm 1.09$ & $1.70 \pm 0.10$ & $177.88 \pm 32.16$ & $17.78 \pm 3.21$ \\
\hline LC & $259.83 \pm 24.76$ & $25.98 \pm 2.47$ & $2.00 \pm-0.10$ & $0.20 \pm-0.01$ & $388.44 \pm-28.21$ & $38.84 \pm-2.82$ \\
\hline EF & $131.38 \pm 2.48$ & $13.13 \pm 0.24$ & $14.39 \pm 0.49$ & $1.43 \pm 0.04$ & $137.87 \pm 4.89$ & $13.78 \pm 0.48$ \\
\hline EC & $292.35 \pm-6.03$ & $29.23 \pm-0.60$ & $2.25 \pm-0.02$ & $0.22 \pm-0.002$ & $157.05 \pm 21.23$ & $15.70 \pm 2.12$ \\
\hline
\end{tabular}

Each concentration of total polyphenols, total flavonoids, and condensed tannins corresponds to the average of three replicates \pm standard deviation 
Antimicrobial Potential of Plant Extracts and Chemical Fractions of Sideroxylon obtusifolium

Table 3: Antimicrobial potential of chemical fractions of the lyophilized hydroalcoholic extracts of bark and leaves of S. obtusifolium against $C$. albicans

\begin{tabular}{|c|c|c|c|c|c|c|c|c|c|c|}
\hline \multirow[b]{3}{*}{ Extracts } & \multicolumn{10}{|c|}{ Antimicrobial potential $(\mu \mathrm{g} / \mathrm{mL})$} \\
\hline & \multicolumn{2}{|c|}{ Hexane fraction } & \multicolumn{2}{|c|}{$\begin{array}{l}\text { Dichloromethane } \\
\text { fraction }\end{array}$} & \multicolumn{2}{|c|}{ Ethyl acetate fraction } & \multicolumn{2}{|c|}{ N-butanol fraction } & \multicolumn{2}{|c|}{$\begin{array}{c}\text { Aqueous solution } \\
\text { fraction }\end{array}$} \\
\hline & $M I C$ & $M F C$ & MIC & $M F C$ & $M I C$ & $M F C$ & $\overline{M I C}$ & $\overline{M F C}$ & $M I C$ & MFC \\
\hline LF & 500 & 1,000 & 250 & 500 & 500 & $>1,000$ & 250 & 500 & $>1,000$ & * \\
\hline LC & 500 & $>1,000$ & 500 & $>1,000$ & 500 & $>1,000$ & 500 & $>1,000$ & 500 & $>1,000$ \\
\hline
\end{tabular}

${ }^{*}$ Not carried out due lack of results in the MIC test

Many plants are frequently used by local populations that have not been studied for their active principles nor identified to validate them as medicines, nor to leverage them economically. ${ }^{16}$

In this perspective of bioprospecting, the results of this study are presented and were compared with the related literature. According to the classification proposed by Holetz et $\mathrm{al}^{25}$ in Table 1, the extract EC presented weak antimicrobial potential on the growth of $S$. mutans (MIC $=1000 \mu \mathrm{g} / \mathrm{mL}$ ). The other extracts were inactive for the Streptococci strains tested. Under the conditions of this study, the result suggested the infeasibility of prospective research on the extract as a potential antimicrobial agent against the strains of $S$. mutans, S. oralis, S. parasanguinis, and S. salivarius.

In this study, it was observed that all of the extracts tested showed antifungal drug potential against $C$. albicans, demonstrating moderate inhibitory activity on growth $(\mathrm{MIC}=500 \mu \mathrm{g} / \mathrm{mL})$, in line with the Holetz et $\mathrm{al}^{25}$ classification. The fungistatic or fungicidal potential could not be assigned because the MFC / MIC relationship value was not well defined $(>1000 / 500)$. We suggest further studies to establish the fungistatic or fungicidal potential of the extracts. The bacterial strains were sensitive to the control substance, chlorhexidine $0.12 \%$, as well as C. albicans to nystatin $100,000 \mathrm{IU} / \mathrm{mL}$, in all concentrations tested. Ethanol at $40 \%$, used as a diluent of the extracts, did not affect the microbial growth in the concentrations tested.

Studies describe the action of S. obtusifolium bark and leaf extracts. Cruz et $\mathrm{al}^{26}$ evaluated the antifungal effect, by diffusion in agar method, of lyophilized extract from Quixabeira bark on fungal species, among them, C. albicans. The authors note that the freeze-dried Quixabeira extract showed no antifungal activity against the species analyzed, in disagreement with the findings in this study, where we observed moderate inhibitory activity on the growth of C. albicans.

Methodological differences among studies may have influenced the different results for the antifungal effect of the freeze-dried bark extract of S. obtusifolium. According to Rocha et $\mathrm{al}^{7}$ the diffusion in agar method, which presents limitations regarding the diffusion capacity of the substance, may have influenced the antifungal effect in the study of Cruz et al, ${ }^{26}$ whereas in this study the action of freeze-dried extract from the Quixabeira bark was satisfactory.

Other factors, such as the regional differences as to the place of plant collection and different concentrations of the extract tested between the experiments can interfere in the potential of the antimicrobial activity of plant species under study. ${ }^{27}$ The seasonality, type of soil, temperature, and climate can also interfere. ${ }^{28,29}$ The method of extract preparation and the part of the plant used are also crucial to unlock the potential of bioactive constituents of studied plant species. ${ }^{26,30}$ Differences as to the production method of extracts were also evidenced between the studies. In this study, we used maceration, and in the study by Cruz et $\mathrm{al}^{26}$ decoction was used.

The antibacterial potential of hydroalcoholic extracts at $70 \%$ of the bark and leaves of S. obtusifolium was evaluated on strains of Staphylococcus aureus, Enterococcus faecalis, and Escherichia coli by diffusion in agar and broth microdilution methods. For the diffusion in agar method, none of the extracts presented activity; however, the broth microdilution method for the bark extract showed bactericidal and bacteriostatic activity on S. aureus and E. coli, while the leaf extract showed the same activities for S. aureus. ${ }^{7}$ The results do not corroborate the findings of Costa et al, ${ }^{31}$ in which a $70 \%$ hydroalcoholic extract of S. obtusifolium bark presented activity against $E$. faecalis using the agar diffusion method.

The variability of results between the experiments that use similar extracts, microorganisms, and techniques may suggest that the antimicrobial activity evaluation of S. obtusifolium hydroalcoholic extracts is influenced by the agar diffusion method.

As to the chemical quantification, in Table 2, the more prevalent compounds in the S. obtusifolium bark and leaves extracts are total polyphenols and condensed tannins. Regarding the polyphenols content, the extract EC stood out, followed by the LC extract. For the quantification of condensed tannins, the extract LC stood out followed by the LF extract. The presence of these compounds may be related to the inhibitory action of the EC extract on the growth of S. mutans, and with the action of the extracts LC and LF on C. albicans, as shown in Table 1. 
The abundant presence of polyphenolic compounds was also reported for ethyl acetate bark extract of S. obtusifolium and may be linked to the antioxidant potential and antibacterial activity presented against $S$. aureus. ${ }^{32}$ This extract corroborates the antimicrobial activity results related to the EC extract in this study, which showed the greatest quantification of total polyphenols, as shown in Table 2, and was the only one that showed inhibitory potential on the growth of $S$. mutans as shown in Table 1. Condensed tannins were quantified in all of the freezedried and ethanol extracts, which presented moderate inhibitory activity on the growth of C. albicans.

The presence of tannins and flavonoids in S. obtusifolium EC extract was also found in a study by AraújoNeto et $\mathrm{al}^{33}$ corroborating the quantification of these compounds in this study.

The ability of tannins to complex with proteins gives them the ability to precipitate these compounds helping, for example, in the inhibition S. mutans glycosyltransferase enzymes, as well as other inhibitory effects on fungi. ${ }^{34}$ This study suggests that the levels of tannins found in Table 2 may have influenced the antibacterial action presented in this study by the EC extract on S. mutans, and the antifungal effects presented by all of the extracts tested on C. albicans, as shown in Table 1.

Since the LF and LC extracts showed moderate antimicrobial activity against $C$. albicans, they were fractionated, aiming to verify the antimicrobial activity in their respective fractions, with possibilities for future studies for isolation of compounds responsible for this action.

According to Table 3, the fractions of dichloromethane and n-butanol of the LF extracts showed moderate inhibitory activity against growth (MIC $=250 \mu \mathrm{g} / \mathrm{mL}$ ) of $C$. albicans and fungicidal potential $(\mathrm{MFC} / \mathrm{MIC}=2)$, with better results as compared with the activity observed in the crude LF extract (Table 1). The hexane fraction showed similar inhibitory activity against fungal growth as compared to that presented by crude LF extract $(\mathrm{MIC}=500 \mu \mathrm{g} / \mathrm{mL})$, however, fungicidal potential (MFC/MIC $=2$ ) was presented, as not previously demonstrated. The increase of the LF antimicrobial potential for dichloromethane and n-butanol fractions may have been influenced by the presence of bioactive compounds with better inhibitory activity on growth, and death of C. albicans when separated from crude extract. This result corroborates with Pereira et $\mathrm{al}_{1}^{35}$ who demonstrated the antifungal activity of n-butanol leaf extracts of $S$. obtusifolium in deleterious effects on the morphology and viability of biofilms treated with this extract, suggesting investigation as a potential alternative for the treatment of Candida biofilms.

Höfling et $\mathrm{al}^{36}$ confirmed the important activity of fractionated plant extracts on clinical isolates of $C$. albicans and inhibition of fungal membrane proteolytic activity, demonstrating an important alternative to control and prevent candidiasis. As for the fractionated bark extracts of S. obtusifolium (LC) in this study, the fractioning of the LC extract did not potentiate its action against $C$. albicans.

Studies on the antimicrobial potential of S. obtusifolium are scarce in the literature. This study opens the precedent of research to explore its antimicrobial potential (especially antifungal) for the isolation of compounds responsible for this specific action.

\section{CONCLUSION}

The S. obtusifolium LF extract dichloromethane and n-butanol fractions showed antifungal activity against C. albicans, and potential for phytocompound bioprospecting to treat periodontal fungal diseases caused by this microorganism. As for the antibacterial activity of S. obtusifolium, satisfactory potential for phytocompound bioprospecting for action against oral diseases on the bacteria tested was not found.

Chemical fractioning revealed polyphenols and condensed tannins as the classes of bioactive compounds with higher contents in the analyzed extracts, which may be related to the antifungal properties demonstrated in this study.

\section{Clinical Significance}

The antifungal effect of S. obtusifolium on C. albicans suggests further study, with the possibility of developing a phytocompound adjuvant therapy to treat oral candidiasis, resistant to conventional therapy. Research for new alternatives to treat fungal diseases of the oral cavity with active ingredients from plants is of clinical relevance and scientific interest, bearing in mind that many antifungal therapeutic agents do not reach expected efficacies due to microbial resistance, or have adverse effects on human tissues.

\section{ACKNOWLEDGMENTS}

The Conselho Nacional de Desenvolvimento Científico e Tecnológico (CNPq), Coordenação de Aperfeiçoamento de Pessoal de Nível Superior (CAPES), and the Universidade Estadual de Campinas/UNICAMP for the promotion and technical partnership through the Program "Casadinho" / PROCAD, transverse action 06/2011 and the State University of Paraíba/UEPB.

\section{REFERENCES}

1. Xiao J, Klein MI, Falsetta ML, Lu B, Delahunty CM, Yates JR 3rd, Heydorn A, Koo H. The exopolysaccharide matrix modulates the interaction between 3D architecture and virulence of a mixed-species oral biofilm. PLoS Pathog 2012;8(4):e1002623. 
2. Zijnge V, van Leeuwen MB, Degener JE, Abbas F, Thurnheer T, Gmür R, Harmsen HJ. Oral biofilm architecture on natural teeth. PLoS One 2010 Feb;5(2):e9321.

3. Cortelli JR, Thénoux RE. The effect of mouthrinses against oral microorganisms. Braz Oral Res 2007;21(Special Issue 1):23-28.

4. Falsetta ML, Klein MI, Colonne PM, Scott-Anne K, Gregoire S, Pai CH, Gonzalez-Begne M, Watson G, Krysan DJ, Bowen WH, et al. Symbiotic relationship between Streptococcus mutans and Candida albicans synergizes virulence of plaque biofilms in vivo. Infect Immun 2014 May;82(5):1968-1981.

5. Neville, BW.; Dam, DD.; Allen, CM.; Bouquot, JE. Patologia Oral e Maxilofacial. 3rd ed. Rio de Janeiro: Elsevier; 2009.

6. Marsh PD. Controlling the oral biofilm with antimicrobials. J Dent 2010 Jun;38 (Suppl 1):S11-S15.

7. Rocha EA, Carvalho AV,AndradeSR, Medeiros AC, Trovão DM, Costa EM. Potencial antimicrobiano de seis plantas do semiárido paraibano contra bactérias relacionadas à infecção endodôntica. Rev Ciênc Farm Básica Apl 2013 Dec;34(3): 351-355.

8. Morais-Braga MF, Souza TM, Santos KK, Guedes GM, Andrade JC, Tintino SR, Costa JG, Menezes IR, Saraiva AÁ, Coutinho HD. Atividade antibacteriana, antifúngica e moduladora da atividade antimicrobiana de frações obtidas de Lygodium venustum SW. Bol Latinoam Caribe Plantas Med Aromát 2013;12(1):38-43.

9. Snowden R, Harrington H, Morrill K, Jeane L, Garrity J, Orian M, Lopez E, Rezaie S, Hassberger K, Familoni D, et al. A comparison of the anti-Staphylococcus aureus activity of extracts from commonly used medicinal plants. J Altern Complement Med 2014 May;20(5):375-382.

10. Beltrão AE, Tomaz AC, Beltrão FA, Marinho P. In vitro biomass production of Sideroxylon obtusifolium (Roem \& Schult). Braz J Pharmacogn 2008 Dec;18:696-698.

11. Silva GMC, Martins PL, Silva H, Freitas KKC. Estudo autoecológico de Bumélia sertorium (Quixabeira) - Espécie ameaçada de extinção no ecossistema Caatinga. Re Biol Ciênc Terra 2004;4(1):81-92.

12. Almeida RN, Filho JM, Naik SR. Chemistry and pharmacology of an ethanol extract of Bumelia sartorum. J Ethnopharmacol 1985 Nov-Dec;14(2-3):173-185.

13. Albuquerque, UP.; Nunes, AT.; Almeida, ALS.; Almeida, CMAD.; Lins Neto, EMF.; Vieira, FJ., Silva FS.; Soldati GT.; Nascimento LGF.; Santos LL., et al. Caatinga: biodiversidade e Qualidade de Vida. Vol. 6. Bauru: Canal; 2010.

14. de Albuquerque UP, Muniz de Medeiros P, de Almeida AL, Monteiro JM, Machado de Freitas Lins Neto E, Gomes de Melo J, dos Santos JP. Medicinal plants of the caatinga (semi-arid) vegetation of NE Brazil: a quantitative approach. J Ethnopharmacol 2007 Dec;114(3):325-354.

15. Passos OliveiraA,RaithM,Kuster RM, RochaLM,HamburgerM, Potterat O. Metabolite profiling of the leaves of the Brazilian folk medicine Sideroxylon obtusifolium. Planta Med 2012 May;78(7):703-710.

16. Alves JJ, Nascimento SS. Levantamento fitogeográfico das plantas medicinais nativas do cariri paraibano. Rev Geogr Acad 2010;4(2):73-85.

17. Clinical and Laboratory Standards Institute. Methods for dilution antimicrobial susceptibility tests for bacteria that grow aerobically; approved standard M7-A6. 6th ed. Wayne (PA): CLSI; 2003.

18. Clinical and Laboratory Standards Institute. Reference method for broth dilution antifungal susceptibility testing of yeasts; approved standard M27-A3. 3rd ed. Wayne (PA): CLSI; 2008.

19. Silva MS, Brandão DO, Chaves TP, Formiga Filho AL, Costa EM, Santos VL, Medeiros AC. Study bioprospecting of medicinal plant extracts of the semiarid northeast: contribution to the control of oral microorganisms. Evid Based Complement Alternat Med 2012;2012:681207.

20. Sarker SD, Nahar L, Kumarasamy Y. Microtitre plate-based antibacterial assay incorporating resazurin as an indicator of cell growth, and its application in the in vitro antibacterial screening of phytochemicals. Methods 2007 Aug;42(4): 321-324.

21. Liu M, Seidel V, Katerere DR, Gray AI. Colorimetric broth microdilution method for the antifungal screening of plant extracts against yeasts. Methods 2007 Aug;42(4):325-329.

22. Chandra S, De Mejia Gonzalez E. Polyphenolic compounds, antioxidant capacity, and quinone reductase activity of an aqueous extract of Ardisia compressa in comparison to mate (Ilex paraguariensis) and green (Camellia sinensis) teas. J Agric Food Chem 2004 Jun;52(11):3583-3589.

23. Meda A, Lamien CE, Romito M, Millogoc J, Nacoulma OG. Determination of the total phenolic, flavonoid and proline contents in Burkina Fasan honey, as well as their radical scavenging activity. Food Chem 2005 Jul;91(3):571-577.

24. Makkar HP, Becker K. Vanillin- $\mathrm{HCl}$ method for condensed tannins: effect of organic solvents used for extraction of tannins. J Chem Ecol 1993 Apr;19(4):613-621.

25. Holetz FB, Pessini GL, Sanches NR, Cortez DA, Nakamura CV, Filho BP. Screening of some plants used in the Brazilian folk medicine for the treatment of infectious diseases. Mem Inst Oswaldo Cruz 2002 Oct;97(7):1027-1031.

26. Cruz MC, Santos PO, Barbosa AM Jr, de Mélo DL, Alviano CS, Antoniolli AR, Alviano DS, Trindade RC. Antifungal activity of Brazilian medicinal plants involved in popular treatment of mycoses. J Ethnopharmacol 2007 May;111(2):409-412.

27. Reis NT, Lelis TC, Mendonça AT, Chavasco JK. Avaliação da ação de extratos vegetais sobre a formação de biofilmes por Candida albicans. Rev Univ Vale Rio Verde 2011;9(2): 337-343.

28. Lubian CT, Teixeira JM, Lund RG, Nascente PS, Del Pino FA. Atividade antifúngica do extrato aquoso de Arctium minus (Hill) Bernh. (Asteraceae) sobre espécies orais de Candida. Rev Bras Plantas Med 2010 Jun;12(2):157-162.

29. Gobbo-Neto L, Lopes NP. Plantas medicinais: fatores de influência no conteúdo de metabólitos secundários. Quím Nova 2007 Feb;30(2):374-381.

30. Alviano WS, Alviano DS, Diniz CG, Antoniolli AR, Alviano CS, Farias LM, Carvalho MA, Souza MM, Bolognese AM. In vitro antioxidant potential of medicinal plant extracts and their activities against oral bacteria based on Brazilian folk medicine. Arch Oral Biol 2008 Jun;53(6):545-552.

31. Costa EM, Evangelista AP, Medeiros AC, Dametto FR, Carvalho RA. In vitro evaluation of the root canal cleaning ability of plant extracts and their antimicrobial action. Braz Oral Res 2012 May-Jun;26(3):215-221.

32. Ruela HS, Leal IC, de Almeida MR, Santos KR, Wessjohann LA, Kuster RM. Antibacterial and antioxidante activities and acute toxicity of Bumelia sartorum Mart., Sapotaceae, a Brazilian medicinal plant. Braz J Pharmacogn 2011 Feb;21(1):86-91.

33. Araújo-Neto V, Bonfim RR, Oliveira VO, Passos AM, Oliveira JP, Lima CA, Mendes SS, Estevam CS, Thomazzi SM. Therapeutic benefits of Sideroxylon obtusifolium (Humb. 
ex Roem. \& Schult.) T.D. Penn., Sapotaceae, in experimental models of pain and inflammation. Braz J Pharmacogn 2010 Dec;20(6):933-938.

34. de Vasconcelos Cabral DL, Sobrinho TJ, de Amorim EL, de Albuquerque UP. Relationship of biometric parameters on the concentration of tannins in two medicinal plants - a case study. Bol Latinoam Caribe Plantas Med Aromát 2010;9(5): 368-376.
35. Pereira JV, Freires IA, Castilho AR, da Cunha MG, Alves Hda S, Rosalen PL. Antifungal potential of Sideroxylon obtusifolium and Syzygium cumini and their mode of action against Candida albicans. Pharm Biol 2016 Oct;54(10):2312-2319.

36. Höfling JF, Mardegan RC, Anibal PC, Furletti VF, Foglio MA. Evaluation of antifungal activity of medicinal plant extracts against oral Candida albicans and proteinases. Mycopathologia 2011 Aug;172(2):117-124. 